\title{
The Role of Ethylene Production in Virulence of Pseudomonas syringae pvs. glycinea and phaseolicola
}

\author{
Helge Weingart, Henriette Ullrich, Klaus Geider, and Beate Völksch
}

First and fourth authors: Friedrich-Schiller-Universität Jena, Institut für Mikrobiologie, Molekulare Phytopathologie, Winzerlaer Str. 10, D07745 Jena, Germany; and second and third authors: Max-Planck-Institut für Zellbiologie, Rosenhof, D-68526 Ladenburg, Germany. Accepted for publication 17 January 2001.

\section{ABSTRACT}

Weingart, H., Ullrich, H., Geider, K., and Völksch, B. 2001. The role of ethylene production in virulence of Pseudomonas syringae pvs. glycinea and phaseolicola. Phytopathology 91:511-518.

The importance of ethylene production for virulence of Pseudomonas syringae pvs. glycinea and phaseolicola was assayed by comparing bacterial multiplication and symptom development in bean and soybean plants inoculated with ethylene-negative (efe) mutants and wild-type strains. The efe mutants of Pseudomonas syringae pv. glycinea were significantly reduced in their ability to grow in planta. However, the degree of reduction was strain-dependent. Population sizes of efe mutant 16/83-E1 that did not produce the phototoxin coronatine were 10- and 15-fold lower

Ethylene $\left(\mathrm{C}_{2} \mathrm{H}_{4}\right)$ functions as a gaseous plant hormone. It has strong effects on numerous physiological processes such as fruit ripening, seed germination, flower development, leaf abscission, and senescence. Plant tissues produce increased amounts of ethylene in response to various environmental factors including wounding, drought, water logging, chilling temperature, and exposure to chemicals $(1,25)$.

Enhanced formation of ethylene is also an early response of plants to pathogen attack (7). Accordingly, it has been suggested that ethylene acts as a signal for defense responses during plantmicrobe interactions. Support for the involvement of ethylene in plant resistance comes from its ability to induce accumulation of pathogenesis-related proteins such as $\beta$-1,3-glucanase and chitinase (22). Moreover, synthesis of other defense-associated proteins like phenylalanine ammonia-lyase or hydroxyproline-rich glycoproteins can be induced by ethylene (7). Ethylene is involved not only in the induction of defense reactions, it may also increase disease severity in some plant-pathogen interactions. Correlation between ethylene production and chlorotic or necrotic symptom development have been reported from various plant species $(2,10$, 17,35). Chlorosis, senescence, and abscission are well-known responses of plants to ethylene, and thus ethylene can promote predisposition of plant tissue to disease. Recently, Hoffman et al. (19) used soybean mutants with reduced sensitivity to ethylene to investigate the role of ethylene in the interactions of soybeans with different pathogens. Although these mutants displayed reduced disease severity in response to some pathogens, they showed more severe disease symptoms with other pathogens. The results obtained by Hoffman et al. (19) demonstrated that the reac-

Corresponding author: B. Völksch; E-mail address: b5bevo@uni-jena.de

Publication no. P-2001-0319-01R

This article is in the public domain and not copyrightable. It may be freely reprinted with customary crediting of the source. The American Phytopathological Society, 2001. than those of the wild-type strain on soybean and on bean, and 16/83-E1 produced very weak symptoms compared with the wild-type strain. The coronatine-producing efe mutant 7a/90-E1 reached fourfold and twofold lower population sizes compared with the wild-type strain on soybean and bean, respectively, and caused disease symptoms typical of the wild-type strain. Experiments with ethylene-insensitive soybeans confirmed these results. The virulence of the wild-type strains was reduced to the same extent in ethylene-insensitive soybean plants as the virulence of the efe mutants in ethylene-susceptible soybeans. In contrast, the virulence of Pseudomonas syringae pv. phaseolicola was not affected by disruption of the efe gene.

Additional keywords: bacterial growth, ethylene-insensitive plants. tion of plant tissue to a pathogen was not uniform, but depended on the particular pathogen.

In addition to plants, various microorganisms including plant pathogens produce ethylene (13). Microbial ethylene biosynthesis pathways are distinct from those of higher plants, in which 1aminocyclopropane-1-carboxylic acid is the precursor of ethylene. Most microorganisms produce only trace amounts of ethylene via 2-keto-4-methyl-thiobutyric acid (KMBA), a transaminated derivative of methionine (28). In this pathway, an NADH:Fe(III)EDTA oxidoreductase catalyzes the formation of hydroxyl radicals that serve as oxidizing agents in the nonenzymatic oxidation of KMBA to ethylene (29).

The most efficient microbial ethylene producers utilize 2oxoglutarate as a substrate. This pathway was found in Pseudomonas syringae pvs. cannabina, glycinea, phaseolicola, pisi, and sesami and in different fungi such as Penicillium digitatum, Penicillium cyclopium, Phycomyces nitens, and Fusarium oxysporum $(13,33,42)$. A single protein, the ethylene-forming enzyme (EFE), is responsible for ethylene formation by these microorganisms (12). EFE catalyzes the formation of ethylene and succinate in an 1-arginine-dependent reaction in a molar ratio of 2:1 (14).

Few attempts have been made to determine the significance of ethylene production by phytopathogenic bacteria during disease development. Studies with ethylene-producing strains of Pseudomonas solanacearum and Xanthomonas citri have shown that enhanced ethylene production in diseased plant tissues was mainly of host origin $(17,23,30)$. However, in a previous study, we demonstrated that Pseudomonas syringae pv. phaseolicola isolated from kudzu beans and Pseudomonas syringae pv. glycinea were able to produce significant amounts of ethylene in planta (41). According to the definition of Durbin (9), bacterial ethylene can also be considered as a phytotoxin, because it is a compound produced by a pathogen during pathogenesis, and plays a role in disease causation. The goal of this study was to evaluate the involvement of ethylene in the virulence of Pseudomonas syringae 
pvs. glycinea and phaseolicola. Therefore, we constructed ethylenedefective (efe) mutants from representative strains of these pathovars and compared their population dynamics and symptom development with that of wild-type strains on bean and soybean plants, respectively. Our results indicate that ethylene production functions as a virulence factor in Pseudomonas syringae $\mathrm{pv}$. glycinea. However, lack of ethylene production had no effect on virulence of Pseudomonas syringae pv. phaseolicola.

\section{MATERIALS AND METHODS}

Bacterial strains and growth conditions. The bacterial strains used in this study are described in Table 1. Pseudomonas strains were routinely cultured on bouillon glycerol agar (37) at $28^{\circ} \mathrm{C}$. Escherichia coli strains were incubated on standard-I agar (Merck AG, Darmstadt, Germany) at $37^{\circ} \mathrm{C}$. When required, kanamycin $(\mathrm{Km})$ and ampicillin (Ap) were added to media at final concentrations of 25 and $100 \mu \mathrm{g} / \mathrm{ml}$, respectively.

Polymerase chain reaction analysis. The oligonucleotide primers EFE-2 (5'-TCGAGTTGCCTACCGAG-3') and EFE-2R (5'-TCAAGTCCTCCAAGTGC-3') (MWG-Biotech AG, Ebersberg, Germany) were used for amplification of the efe gene of Pseudomonas syringae strains. These primers are located between nucleotides 20 to 36 and 1,002 to 1,018 bp in efe (12). The standard reaction mixture $(50 \mu \mathrm{l})$ contained $67 \mathrm{mM}$ Tris $/ \mathrm{HCl}(\mathrm{pH} \mathrm{8.8)}$, $16 \mathrm{mM}\left(\mathrm{NH}_{4}\right)_{2} \mathrm{SO}_{4}, 3.5 \mathrm{mM} \mathrm{MgCl}, 10 \mathrm{mM}$ 2-mercaptoethanol, $160 \mu \mathrm{g}$ of bovine serum albumin, 5\% dimethylsulfoxide, $1 \%$ Tween 20, $200 \mu \mathrm{M}$ each dNTP, 0.8 units of Taq DNA polymerase (Pharmacia, Freiburg, Germany), 25 pmol of each primer, and $50 \mathrm{ng}$ of DNA (6). Amplification included initial denaturation $\left(95^{\circ} \mathrm{C}, 3 \mathrm{~min}\right)$ followed by 30 cycles of denaturation $\left(94^{\circ} \mathrm{C}, 1 \mathrm{~min}\right)$, annealing $\left(60^{\circ} \mathrm{C}, 1 \mathrm{~min}\right)$, and extension $\left(72^{\circ} \mathrm{C}, 1 \mathrm{~min}\right)$ with a final extension step for $10 \mathrm{~min}$. Polymerase chain reactions (PCR) were done with a Gene ATAQ Controller (Pharmacia).

Site-directed insertional mutagenesis. The efe gene of Pseudomonas syringae pv. glycinea 19/84 was amplified by PCR using oligonucleotide primers EFE-2 and EFE-2R. The amplification product was cloned into the expression vector pGEM-T (Promega GmbH, Mannheim, Germany) to generate pGEM-efe1.

The 1.7-kb vector pfdA8 (15) containing a kanamycinresistance cassette was digested with EcoRI and subcloned by a blunt-end ligation into the unique $\mathrm{NruI}$ restriction site of efe in pGEM-efe1. The resulting vector pGEM-efe1::pfdA8 (Fig. 1) was transformed into E. coli S17-1 by standard methods. Plasmids were prepared from selected transformants with alkaline lysis (32).
Marker exchange mutagenesis. Plasmid pGEM-efe1::pfdA8, which does not replicate in Pseudomonas syringae strains, was transformed into competent cells with a Gene Pulser (Bio-Rad Laboratories GmbH, Munich, Germany). After electroporation, the bacteria were grown at $28^{\circ} \mathrm{C}$ for $3 \mathrm{~h}$ in SOC broth (32) and plated on King's medium B (KB) (21) containing kanamycin. To exclude mutants that result from single cross-over events, Kmresistant colonies were transferred onto $\mathrm{KB}$ medium agar plates containing either Ap or Km. Fluorescent $\mathrm{Km}^{\mathrm{R}}$ (kanamycin-resistant) and $\mathrm{Ap}^{\mathrm{S}}$ (ampicillin-sensitive) colonies were selected as potential efe mutants. Mutants were tested for ethylene production and screened by PCR and Southern blot analysis for the correct insertion of the resistance cassette into efe.

Southern blot analysis. Southern blots were performed as described by Sambrook et al. (32) using a digoxigenin (DIG) DNA labeling and detection kit (Boehringer-Mannheim, Mannheim, Germany). DIG labeled DNA probes were prepared from a PCR amplification product with the efe gene from Pseudomonas syringae pv. phaseolicola $\mathrm{PK} 2$ and with plasmid pfdA8. Hybridizations were performed at a hybridization temperature of $68^{\circ} \mathrm{C}$ and the filters were washed $2 \times 10$ min with $0.1 \times$ $\mathrm{SSC}(1 \times \mathrm{SSC}$ is $0.15 \mathrm{M} \mathrm{NaCl}$ plus $0.015 \mathrm{M}$ sodium citrate) and $0.1 \%$ sodium dodecyl sulfate at $68^{\circ} \mathrm{C}$.

Determination of bacterial ethylene production. Strains were grown overnight in 5a-medium (37) at $28^{\circ} \mathrm{C}$. One milliliter of the culture was transferred to a sterile 5-ml syringe sealed with a rubber cap and incubated on a rotary shaker at $90 \mathrm{rpm}$ and $28^{\circ} \mathrm{C}$ for $2 \mathrm{~h}$. After incubation, gas samples $(1 \mathrm{ml})$ were withdrawn by a gas-tight syringe, and ethylene was determined with a GC-14A gas chromatograph (Shimadzu Scientific Instruments Inc., Duisburg, Germany) equipped with an active aluminum column and a flame ionization detector. Bacterial growth was estimated by the optical density of the bacterial cultures at $578 \mathrm{~nm}$. Ethylene production rate was expressed in nanoliters per hour per cell.

Determination of ethylene production in infected leaves. Twenty discs ( $7 \mathrm{~mm}$ in diameter) were excised with a cork borer from infected leaves at several time intervals and transferred to 3 -ml syringes ( 5 discs per syringe) sealed with rubber caps and incubated at room temperature $\left(22\right.$ to $\left.24^{\circ} \mathrm{C}\right)$ for $6 \mathrm{~h}$. A 1-ml gas sample was taken from each syringe, and ethylene production was determined as previously described. The amount of ethylene produced was calculated in picoliters per hour per leaf disc. After determination of the ethylene concentration, the bacterial population in the leaf discs was enumerated. The leaf discs were combined and macerated in $20 \mathrm{ml}$ of isotonic $\mathrm{NaCl}$. Serial dilutions

TABLE 1. Bacterial strains and plasmids used in this study

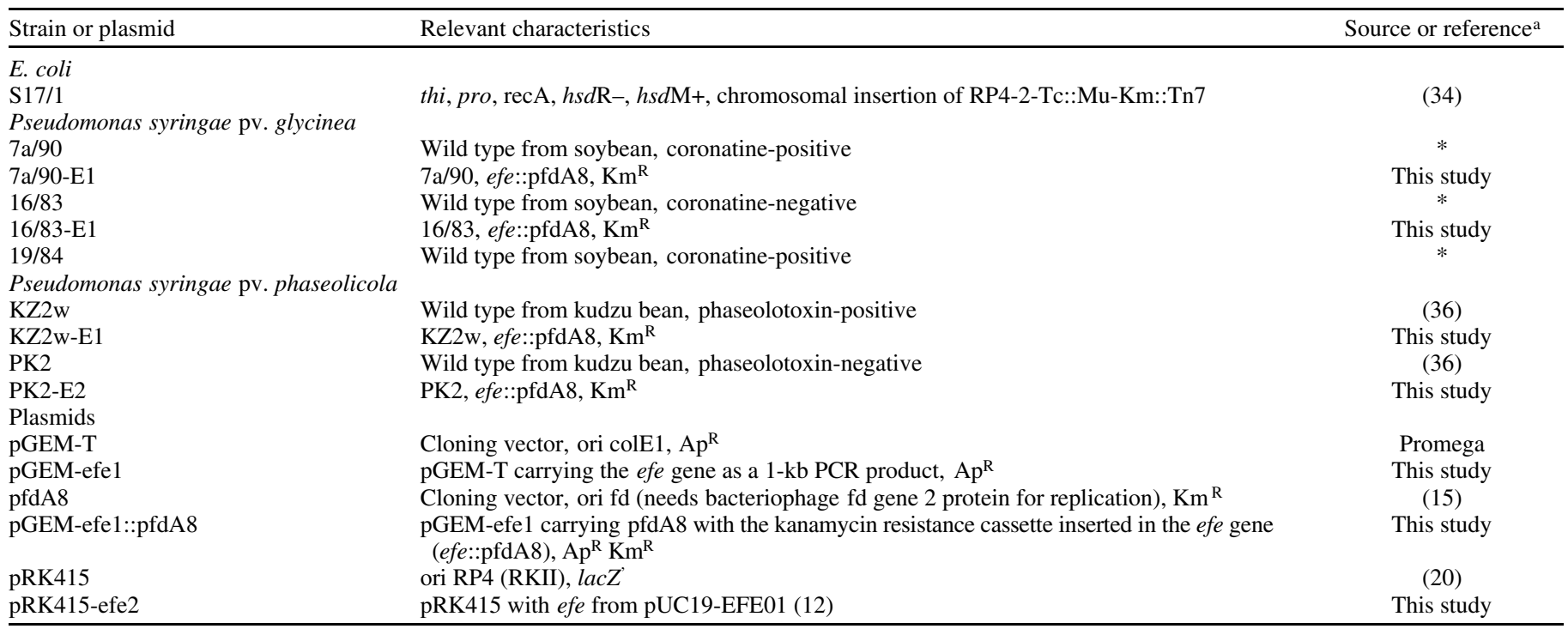

a * Indicates collection B. Völksch, University of Jena. 
were plated on $\mathrm{KB}$ medium to determine the number of bacteria pear leaf disc. Plates were incubated at $28^{\circ} \mathrm{C}$, and colonies from three replica plates were counted after 3 days.

Virulence tests. The virulence of bacterial strains was tested on soybean (Glycine max L. Merr. cv. Maple Arrow) and bean (Phaseolus vulgaris L. cv. Red Kidney). Additionally, plants of the ethylene-insensitive soybean line T119N54 and of isogenic wild-type soybeans cv. Hobbit 87 were used for virulence tests (19). Plants were grown in individual pots in a greenhouse at 22 to $25^{\circ} \mathrm{C}$ with supplemental light for a $14 \mathrm{~h}$ photoperiod. Plants were inoculated by the prick technique as described by May et al. (26). Bacterial suspensions (approximately $10^{5} \mathrm{CFU} / \mathrm{ml}$ ) were dropped $(5 \mu \mathrm{l})$ on each wound (10 per leaf) of pin-pricked leaves. Plants were monitored daily for symptom development. Bacterial populations in leaf wounds were determined by punching 20 discs (7-mm diameter) from the inoculated leaf area. The discs were homogenized in $20 \mathrm{ml}$ of sterile isotonic $\mathrm{NaCl}$ and serially diluted for plating on $\mathrm{KB}$ medium. All greenhouse experiments were repeated at least three times to confirm reproducibility and to calculate standard deviations.

Statistical methods. Statistical calculation were performed using Stanford Graphics (version 2.1c, Softline GmbH, Oberkirch, Germany) for graphics and calculation of standard deviation.

\section{RESULTS}

Site-directed insertional mutagenesis of the efe gene. Plasmid pGEM-efe1::pfdA8 was used to create efe mutants of Pseudomonas syringae pv. glycinea $7 \mathrm{a} / 90$ and 16/83, and of Pseudomonas syringae pv. phaseolicola KZ2w and PK2, by marker exchange mutagenesis. These strains were chosen because they differ in their ability to produce phytotoxins (39). Pseudomonas syringae pv. glycinea $7 \mathrm{a} / 90$ produces coronatine while Pseudomonas syringae pv. phaseolicola $\mathrm{KZ2}$ w produces phaseolotoxin. In contrast, Pseudomonas syringae pv. glycinea 16/83 and Pseudomonas syringae pv. phaseolicola $\mathrm{PK} 2$ produce neither of these toxins.

Several transformants were tested for their ability to synthesize ethylene. The $\mathrm{Ap}^{\mathrm{S}} \mathrm{Km}^{\mathrm{R}}$ transformants failed to produce detectable amounts of ethylene (Table 2). A PCR-based assay was performed to confirm homologous integration of recombinant vector DNA in the efe locus. A 1-kb PCR product was found for the wild-type gene when amplified with the primers EFE2 and EFE-2R. PCR analysis of the $\mathrm{Ap}^{\mathrm{S}} \mathrm{Km}^{\mathrm{R}}$ transformants Pseudomonas syringae $\mathrm{pv}$. glycinea 7a/90-E1, 16/83-E1, and Pseudomonas syringae $\mathrm{pv}$. phaseolicola KZ2w-E1 and PK2-E2 resulted in 2.7-kb PCR products from efe with the pfdA8 insertion. The lack of the 1-kb band indicated that the efe gene of these transformants was inactivated by homologous recombination (data not shown).

Characterization of efe mutants with Southern blots and complementation. The mutants obtained for the Pseudomonas syringae pathovars were investigated for the correct chromosomal

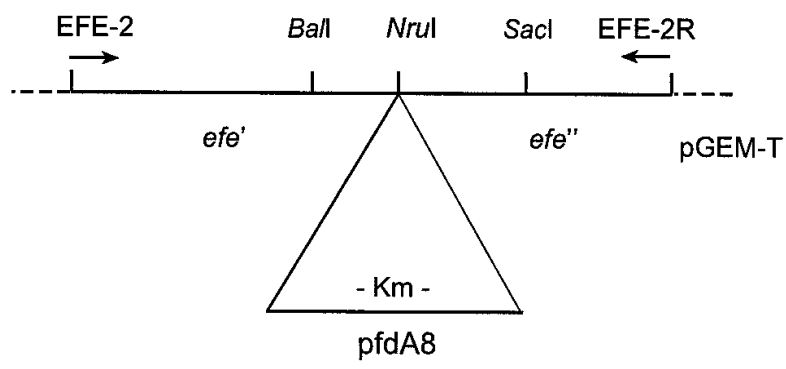

Fig. 1. Map of plasmid pGEM-efe1::pfdA8. The cloned part $(1 \mathrm{~kb})$ of $e f e$ is presented with major restriction sites and insertion of the resistance cassette pfdA8 into the NruI site (solid lines). The broken line indicates part of vector pGEM-T. integration of plasmid pGEM-efe1::pfdA8. DIG-labeled DNA with the efe gene and plasmid pfdA8 highlighted a single DNA fragment (Fig. 2). A HincII digest of parental and mutant DNA revealed an identical size for three strains and a restriction fragment length polymorphism in case of the Pseudomonas syringae pv. phaseolicola strain PK2. Thus, DNA fragments were shifted for the mutants by the size difference of pfdA8. These results confirm a single recombination event of plasmid pGEM-efe1:: pfdA8 in the bacterial chromosomes with a double cross-over for mutated strains.

A DNA fragment with the efe gene was isolated from plasmid pUC19-EFE01 (12), which was cut with restriction enzyme HindIII. A fragment of $2.5 \mathrm{~kb}$ was inserted into vector pRK415 (20) to create pRK415-efe2, which can replicate in Pseudomonas syringae strains. The plasmid with the efe gene was transformed into Pseudomonas syringae pv. phaseolicola by electroporation. Ethylene synthesis was determined for the wild-type strain PK2, the mutant PK2-E2, and PK2-E2(pRK415-efe2). Ethylene production was restored by the plasmid carrying efe, indicating the mutation in the structural gene for the EFE of PK2 (Table 2).

Contribution of ethylene production to virulence of Pseudomonas syringae pv. glycinea. The involvement of ethylene in virulence was evaluated by monitoring the bacterial population dynamics and the development of disease symptoms on soybean (cv. Maple Arrow) and bean (cv. Red Kidney). For virulence tests, leaves were inoculated by the prick technique (26). This technique mimics the natural infection process, in which pathogens often enter the plant through open wounds. One advantage of this method is the ability to inoculate a defined number of bacterial cells on the pin-pricked wounds. Moreover, wild-type strain and mutant could be inoculated simultaneously on one leaf, left and right of the midrib, respectively. Thus, the wild-type strain and the mutant grew under identical conditions.

Disease symptoms caused by the efe mutant of the coronatineproducing strain Pseudomonas syringae pv. glycinea 7a/90 were indistinguishable from those caused by the wild-type strain. Necrotic spots surrounded by strong chlorotic halos were visible within 9 to 12 days after inoculation of soybean. Bean leaves inoculated with these strains showed only weak chlorosis. The wild-type strain reached a population density of $2 \times 10^{7} \mathrm{CFU}$ per leaf disc on soybean, and $2 \times 10^{5} \mathrm{CFU}$ per leaf disc on bean (Fig. $3 \mathrm{~A}$ and B). Mutant 7a/90-E1 multiplied to the same extent during the first 7 days after inoculation in soybean leaves. Afterwards, differences in the multiplication rates of the wild-type strain and the mutant increased continuously. At 21 days after inoculation, the population size of the wild-type strain was fourfold higher than that of the efe mutant (Fig. 3A). Bacterial growth on bean leaves showed that the mutant reached a twofold lower population size than the wild-type strain during the 21-day sampling period (Fig. 3B).

TABLE 2. Ethylene production by wild-type strains and derivatives of Pseudomonas syringae pvs. glycinea and phaseolicola

\begin{tabular}{lc}
\hline Strains & $\begin{array}{c}\text { Ethylene production } \\
10^{-8} \mathrm{nl} \mathrm{h}^{-1} \text { cell }^{-1}\end{array}$ \\
\hline P. syringae pv. glycinea & $30.7 \pm 5.4$ \\
7a/90 & 0 \\
$7 \mathrm{a} / 90$-E1 & $72.9 \pm 7.4$ \\
16/83 & 0 \\
16/83-E1 & $39.3 \pm 4.8$ \\
$P$. syringae pv. phaseolicola & 0 \\
KZ2w & $26.4 \pm 6.8$ \\
KZ2w-E1 & 0 \\
PK2 & $29.2 \pm 7.6$ \\
PK2-E2 &
\end{tabular}

${ }^{a}$ Data represent the mean and standard deviation of five independent determinations. 
The ethylene-negative mutant of Pseudomonas syringae pv. glycinea strain 16/83 showed a greater reduction in virulence than the efe mutant 7a/90-E1 in comparison to their parent strains. Strain $16 / 83$ is not able to produce the phytotoxin coronatine. The wild-type strain reached a population size of $5 \times 10^{6} \mathrm{CFU}$ per leaf disc on soybean, whereas the population size of the efe mutant $16 / 83$-E1 was roughly 10-fold lower throughout most of the sampling period (Fig. 3C). When inoculated into soybean leaves, the wild-type strain $16 / 83$ produced typical disease symptoms (necrotic lesions surrounded by chlorotic halos). Consistent with the lower population size of $16 / 83-E 1$, only very weak or no disease symptoms were observed on soybean leaves inoculated with this mutant.

In bean leaves, Pseudomonas syringae pv. glycinea 16/83 reached the low population size of $8 \times 10^{3}$ CFU per leaf disc without visible disease symptoms. The population size of the mutant 16/83-E1 was approximately 15 -fold lower than those of the wild-type strain on bean (Fig. 3D).

Behavior of Pseudomonas syringae pv. glycinea efe mutants on ethylene-insensitive soybeans. Recently, Hoffman et al. (19) mutagenized soybeans cv. Hobbit 87 to generate soybean lines with reduced sensitivity to ethylene. They were able to isolate a soybean line, T119N59, which is ethylene-insensitive by a mutation in the ethylene receptor Etr1. The Pseudomonas syringae pv. glycinea strains $7 \mathrm{a} / 90$ and $16 / 83$ and their efe mutants were inoculated into leaves of parental and ethylene-insensitive soybean plants to ascertain whether the reduction in virulence observed for the efe mutants on soybean plants cv. Maple Arrow was due to lack of ethylene production.

As with soybean plants of cv. Maple Arrow, a significant reduction in growth of the efe mutants was observed on infected leaves of soybean plants of cv. Hobbit 87. The Pseudo- monas syringae pv. glycinea strains $7 \mathrm{a} / 90$ and $16 / 83$ reached population sizes of $5 \times 10^{6}$ and $1 \times 10^{6} \mathrm{CFU}$ per leaf disc on soybeans cv. Hobbit 87, respectively. In contrast, the efe mutant 7a/90-E1 reached a fivefold lower, and 16/83-E1 even a 10-fold lower population size (Fig. 4A and C). No difference in the development of disease symptoms was observed between the strains $7 \mathrm{a} / 90$ and 7a/90-E1. However, when soybeans cv. Hobbit 87 were inoculated with $16 / 83$ and $16 / 83$-E1, only the wild-type strain $16 / 83$ was able to cause typical necrotic lesions surrounded by chlorotic halos.

After inoculation into leaves of the ethylene-insensitive soybean line T119N59, both efe mutants and the wild-type strains achieved similar population sizes. However, strains $7 \mathrm{a} / 90$ and $7 \mathrm{a} / 90-\mathrm{E} 1$ reached population sizes of approximately $1 \times 10^{6} \mathrm{CFU}$ per leaf disc and strains $16 / 83$ and 16/83-E1 grew to approximately $1 \times$ $10^{5} \mathrm{CFU}$ per leaf disc (Fig. 4B and D). These values correspond to the population sizes which the efe mutants reached on soybean plants of cv. Hobbit 87. Our results clearly indicate that the lack of ethylene production leads to reduced growth. Moreover, no difference in disease symptoms produced by efe mutants and wildtype strains was observed on leaves of T119N59. Strains 7a/90 and 7a/90-E1 caused typical symptoms, whereas both 16/83 and 16/83-E1 developed only very weak or no symptoms.

Contribution of ethylene production to virulence of Pseudomonas syringae pv. phaseolicola. The virulence of the Pseudomonas syringae pv. phaseolicola strains KZ2w and PK2 was compared with that of the efe mutants KZ2w-E1 and PK2-E2 after inoculation into soybean (cv. Maple Arrow) and bean (cv. Red Kidney) leaves (Fig. 5). Both Pseudomonas syringae pv. phaseolicola strains were isolated from kudzu beans (Pueraria lobata [Willd.] Ohwi), a common weed in Japan $(16,36)$. However, the natural host of these strains was not included in these investi-

A

\section{P M 123455678 M P}

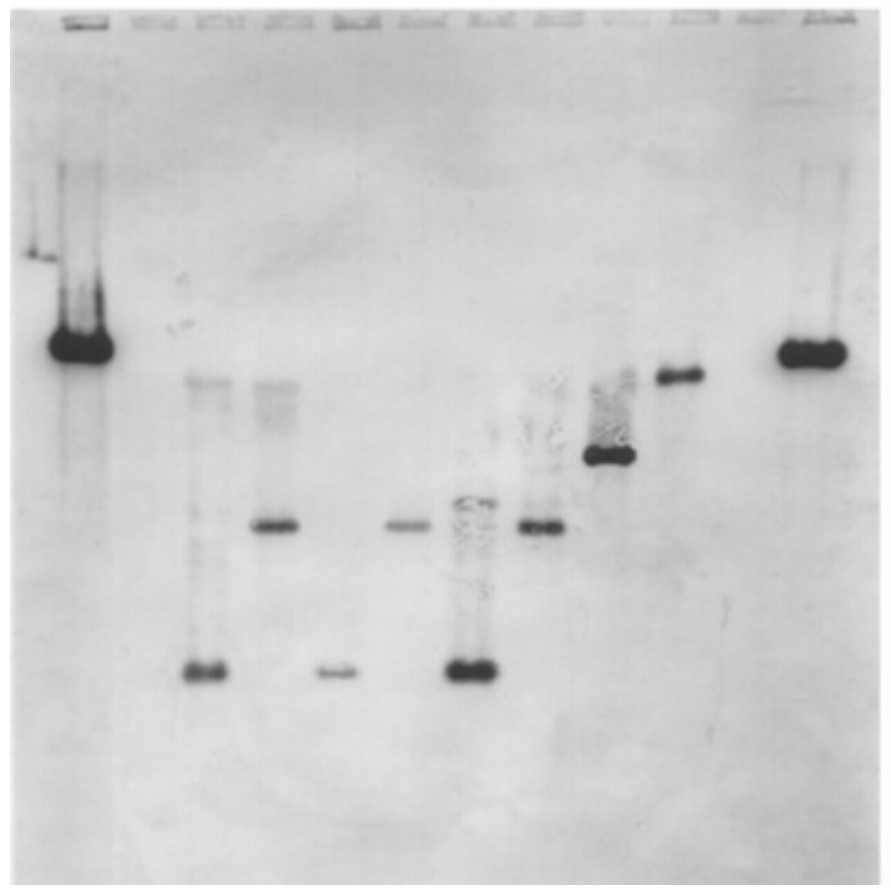

B

\section{PM 123455678 M P}

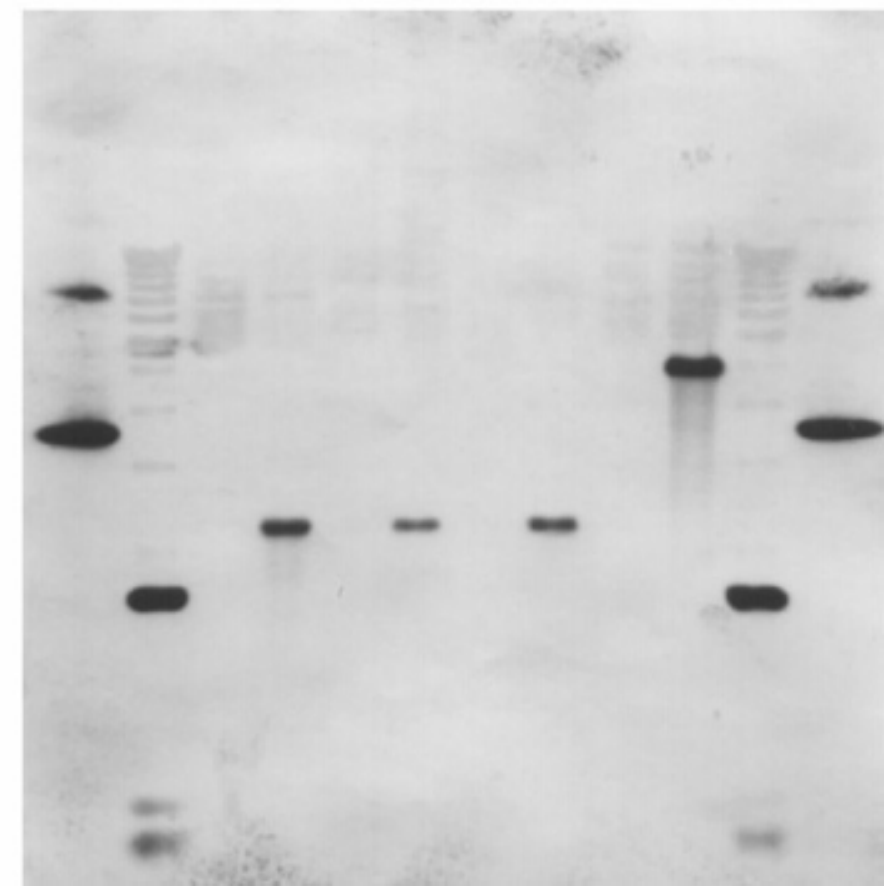

Fig. 2. Southern blot hybridization of HincII-digested genomic DNA from Pseudomonas syringae. A, The probe was digoxigenin (DIG)-labeled DNA with the efe gene from Pseudomonas syringae pv. phaseolicola PK2. B, The probe was DIG-labeled DNA of plasmid pfdA8 containing a kanamycin resistance cassette. Lane P, plasmid pGEM-efe1::pfdA8; lane M, molecular weight marker of $1.74 \mathrm{~kb}$ (pfdA8, HincII-digested for A, undigested for B) with a ladder of nonhybridizing DNA fragments; lane 1, Pseudomonas syringae pv. glycinea 7a/90; lane 2, Pseudomonas syringae pv. glycinea 7a/90-E1; lane 3, Pseudomonas syringae pv. glycinea 16/83; lane 4, Pseudomonas syringae pv. glycinea 16/83-E1; lane 5, Pseudomonas syringae pv. phaseolicola KZ2w; lane 6, Pseudomonas syringae pv. phaseolicola KZ2w-E1; lane 7, Pseudomonas syringae pv. phaseolicola PK2; and lane 8, Pseudomonas syringae pv. phaseolicola PK2-E2. 
gations. The two Pseudomonas syringae pv. phaseolicola strains differ in their ability to produce the phytotoxin phaseolotoxin. KZ2w produces phaseolotoxin, whereas PK2 cannot produce this phytotoxin.

In general, the efe mutants of the Pseudomonas syringae pv. phaseolicola strains were as virulent as the wild-type strains. Mutants and wild-type strains reached similar population sizes on soybean as well as on bean leaves (Fig. 5). No significant difference in the development of disease symptoms was observed. All strains produced necrotic lesions surrounded by chlorotic halos. These results suggest that disruption of the efe gene in the Pseudomonas syringae pv. phaseolicola strains did not affect their virulence on soybean and on bean.

Ethylene production in infected leaf tissue. Previous results demonstrated that the ethylene production in soybean leaves infected with ethylene-producing Pseudomonas syringae pv. glycinea strains was mainly of bacterial origin (41). In those studies, AVG (2-aminoethoxyvinylglycine), an effective inhibitor of ethylene biosynthesis of higher plants, but not of microbial ethylene production, was used to determine the contribution of plant tissue and bacteria to ethylene release from infected leaves. In the present study, we compared ethylene production in leaves infected with an ethylene-producing strain with that of leaves infected with an ethylene-negative mutant.

In leaves inoculated with Pseudomonas syringae pv. glycinea strain $7 \mathrm{a} / 90$, ethylene was produced at a rate of approximately 80 picoliters per hour per leaf disc 6 days after inoculation. Ethylene production by the infected leaf tissue directly correlated with the bacterial growth. The highest rate of ethylene production was detected when the strain $7 \mathrm{a} / 90$ reached the late exponential growth phase (day 6; Fig. 6). In contrast, no increase in ethylene pro- duction was observed when the $e f e$ mutant $7 \mathrm{a} / 90$-E1 was inoculated into soybean leaves. The infected tissue produced ethylene with a rate of only $10 \mathrm{pl}$ per hour per leaf disc during the 21-day sampling period (Fig. 6). These results indicate that enhanced formation of ethylene by the plant is not involved in a defense reaction of soybean leaves against compatible Pseudomonas syringae pv. glycinea strains.

\section{DISCUSSION}

The most efficient bacterial ethylene producers are plant pathogens belonging to certain pathovars of Pseudomonas syringae $(33,39)$. In the present paper, we looked for the role of ethylene in the virulence of Pseudomonas syringae pvs. glycinea and phaseolicola on soybean and bean plants. In order to address this question, marker exchange mutagenesis was used to create ethylene-negative mutants. The comparison of symptom severity and bacterial multiplication demonstrated that efe mutants of Pseudomonas syringae pv. glycinea strains were significantly reduced in their virulence. The efe mutant 16/83-E1 reached 10-fold to 15 -fold lower population sizes in comparison to the wild-type strain in soybean and bean leaves. Moreover, this mutant caused only weak disease symptoms on both plants, whereas the wild-type strain produced typical necrotic lesions surrounded by chlorotic margins. However, smaller differences in virulence were observed between strains 7a/90 and 7a/90-E1. In contrast to Pseudomonas syringae pv. glycinea $16 / 83$, strain $7 \mathrm{a} / 90$ is able to produce coronatine. Coronatine is thought to act as a molecular mimic of octadecanoid signaling molecules produced by higher plants $(18,40)$. It is possible that lack of ethylene production in mutant $7 \mathrm{a} / 90-\mathrm{E} 1$ is in part compensated by the production of this phytotoxin. Both
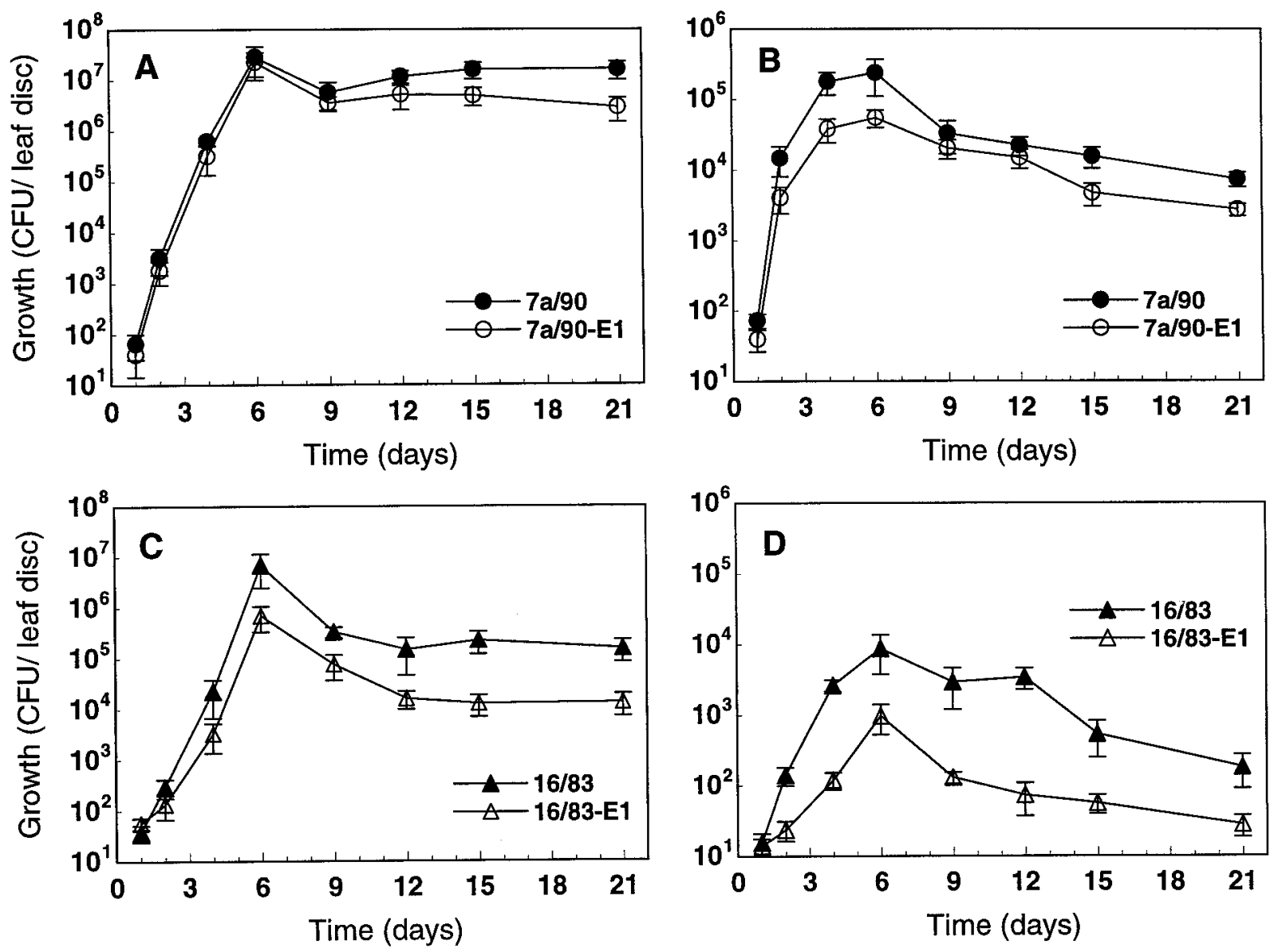

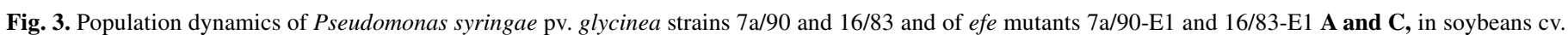
Maple Arrow and B and D, beans cv. Red Kidney. The standard deviation was calculated from four series of samples with 20 leaf discs. 
compounds, ethylene and coronatine are well-known inducers of chlorosis $(3,25)$.

Recently, Hoffman et al. (19) isolated ethylene-insensitive soybean mutants to examine the role of ethylene in the interaction of this plant with different pathogens. These mutants were compared with the parental plants in their response to Pseudomonas syringae pv. glycinea. Reduced disease severity, especially regarding the development of chlorosis, was observed in the ethylene-insensitive mutants, and this was consistent with our findings. In the present study, the ethylene-insensitive soybean line T119N54 was used to ascertain that the introduced resistance cassette did not cause indirect effects on the virulence of the efe mutants. After inoculation of the Pseudomonas syringae pv. glycinea strains into leaves of the parental soybeans (cv. Hobbit 87 ), we found a significant reduction in virulence for the efe mutants as compared to the wild-type strains. However, when inoculated into leaves of the ethylene-insensitive soybean, the wild-type strains reached population sizes similar to those of the efe mutants. The virulence of the wild-type strains in ethyleneinsensitive soybeans was reduced to the same extent as the virulence of the efe mutants in ethylene-susceptible soybeans. These results indicate that reduction in virulence was due to lack of ethylene production. In contrast to Pseudomonas syringae pv. glycinea, ethylene appears not to function as a virulence factor in Pseudomonas syringae pv. phaseolicola on soybean and bean plants. No differences in population sizes or symptom severity were found between efe mutants and wild-type strains of this pathovar. Interestingly, only Pseudomonas syringae pv. phaseolicola strains isolated from kudzu bean (Pueraria lobata) are able to produce ethylene (41). In general, these strains are highly virulent on different Leguminosae plants (38). They cause strong chlorosis on bean, soybean, and kudzu bean within the first 3 days after inoculation. The lack of correlation between ethylene production and virulence in Pseudomonas syringae pv. phaseolicola suggests that ethylene is not required for the infection of bean and soybean plants by these strains or that the loss of ethylene production is compensated by increased production of other virulence factors.

When genes for production of phytotoxins were mutagenized in Pseudomonas syringae pathovars, a similar reduction in virulence as for efe mutants of Pseudomonas syringae pv. glycinea was found. To correlate coronatine production and virulence, Bender et al. (4) used Tn5 mutagenesis to isolate Pseudomonas syringae pv. tomato mutants. These coronatine-negative mutants caused only very small necrotic lesions and reached 10- to 15-fold lower population sizes than the wild-type strain. The role of coronatine as a virulence factor has also been shown for coronatine-insensitive (coi1) Arabidopsis thaliana mutants (11). A coronatine-producing Pseudomonas syringae pv. atropurpurea strain grew in leaves of wild-type A. thaliana to population sizes more than 100 -fold higher than in a coil mutant. Mittal and Davis (27) infected $A$. thaliana and tomato plants with either the coronatineproducing strain Pseudomonas syringae pv. tomato DC3000 or the coronatine-negative derivative DC3661. After inoculation of plants by dipping leaves in a bacterial suspension, DC3661 did not develop any disease symptoms and reached population sizes which were approximately 3 orders of magnitude lower than those of DC3000. Furthermore, analysis of a Pseudomonas syringae pv. syringae mutant unable to produce syringomycin demonstrated that this $\operatorname{syr} P$ mutant was substantially less virulent than the wild-
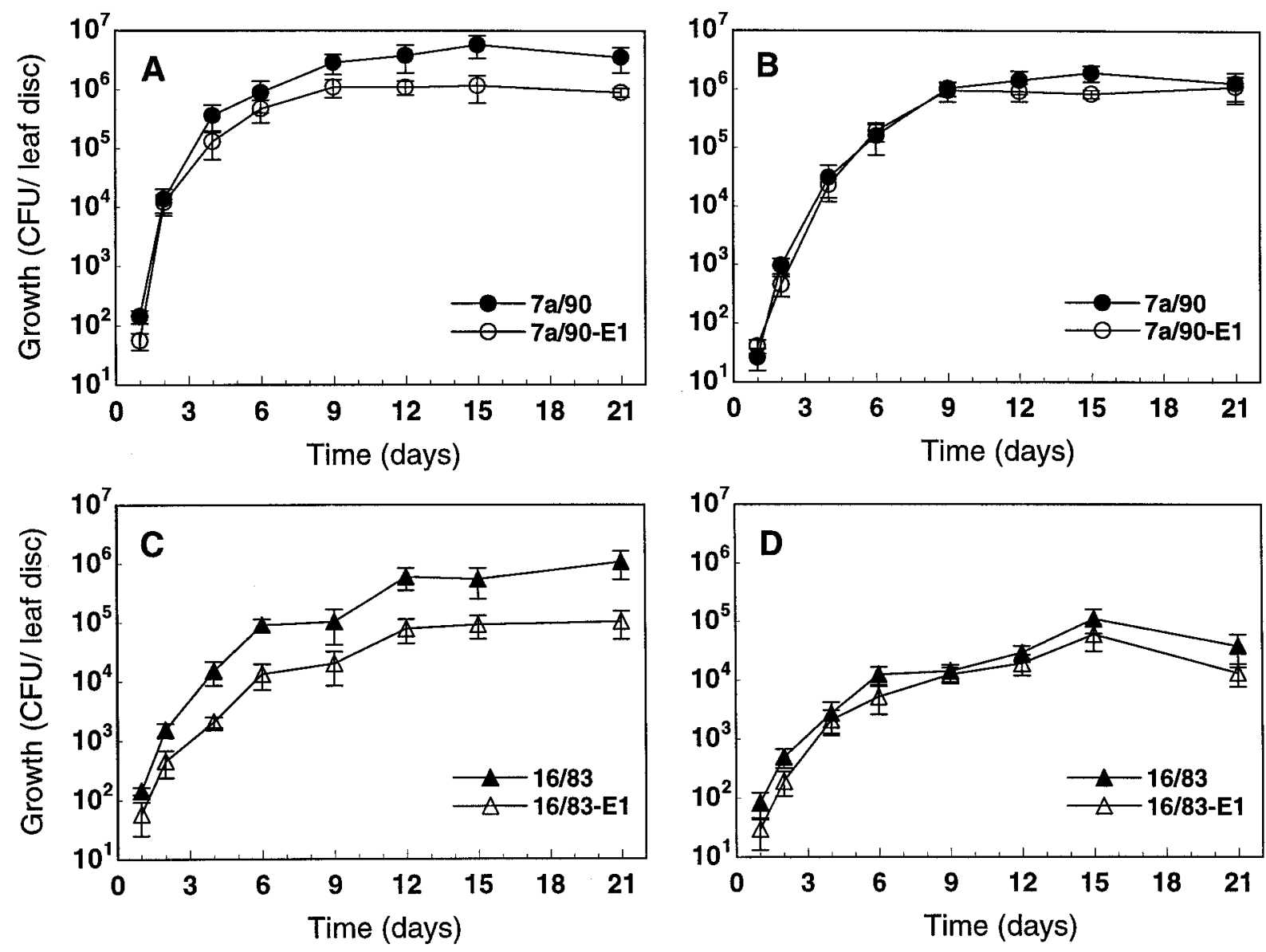

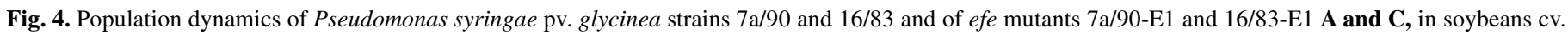

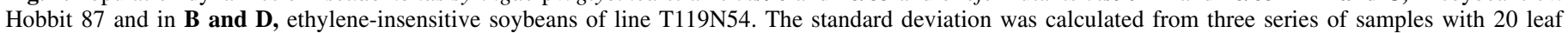
discs. 
type strain in pathogenicity assays in cherry fruits (43). The syrP mutant showed a reduction in lesion formation of approximately $60 \%$ and a 10 -fold lower population size compared with parental strain.

Our results indicate that the production of ethylene increases the virulence of Pseudomonas syringae pv. glycinea strains. But how does ethylene contribute to bacterial virulence? Ethylene is a phytohormone that influences numerous physiological processes during plant growth and development. Microbial synthesis of ethylene may create a hormonal imbalance in the infected plant tissue that could weaken the plant defense and therefore increase the extent of disease expression. It was shown that ethylene enhances the rate of symptom progression in various plant-pathogen interactions (7). Several studies reported a direct correlation between ethylene production of diseased plants and the development of chlorosis and leaf abscission $(2,10,17,35)$. Additional support for ethylene's causal role in foliar disease development comes from studies with ethylene-insensitive A. thaliana and tomato plants $(5,24)$. Mutant plants impaired in ethylene perception exhibited a significant reduction in disease symptoms after inoculation with bacterial pathogens. The pathogens reached similar population sizes in ethylene-insensitive and wild-type plants, indicating that reduction in symptoms was a specific effect of ethylene insensitivity. Ethylene was also shown to be involved in the induction of resistance responses in plants. Ethylene-insensitive soybean plants displayed both reduced and greater disease severity in comparison to wild-type soybeans dependent on the particular pathogen (19). These results demonstrate that, in a given type of plant tissue, ethylene induces a defense reaction and accelerates the development of disease symptoms depending on the attacking pathogen. However, they also found that in the special interaction of soybean and Pseudomonas syringae pv. glycinea ethylene is associated with the progression of disease symptoms, and this agrees with our results.

Different signaling pathways that include jasmonic acid, ethylene, or salicylic acid as signal molecules induce the expression of defense-related genes in plants (8). Each of these signal compounds stimulates the expression of a certain set of defense genes. Depending on the particular pathogen, a plant is able to fine-tune the induction of defense-related genes by employing a single signal molecule or a combination of signals $(8,31)$.

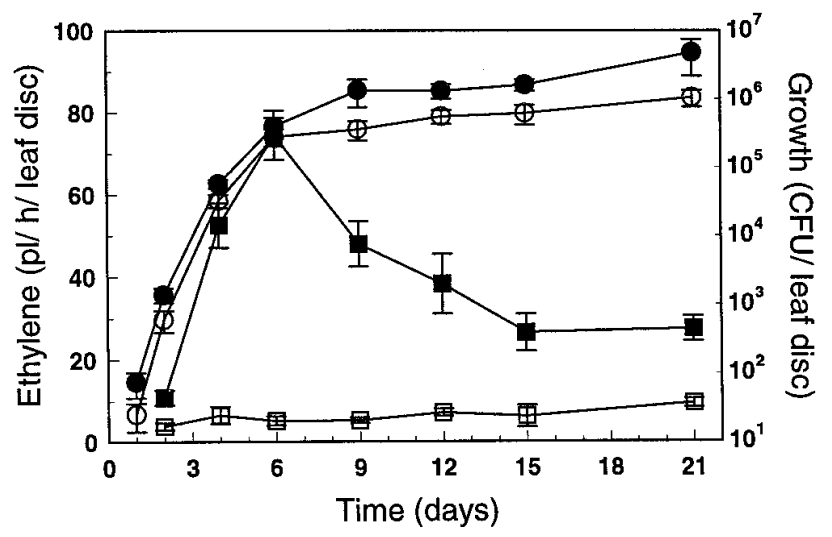

Fig. 6. Population dynamics of Pseudomonas syringae pv. glycinea strain $7 \mathrm{a} / 90(-)$ and efe mutant 7a/90-E1 (O) in soybeans cv. Maple Arrow and ethylene production of the leaf tissue infected with 7a/90 (ם) and 7a/90-E1 $(\square)$, respectively. The standard deviation was calculated from three series of samples with 20 leaf discs.
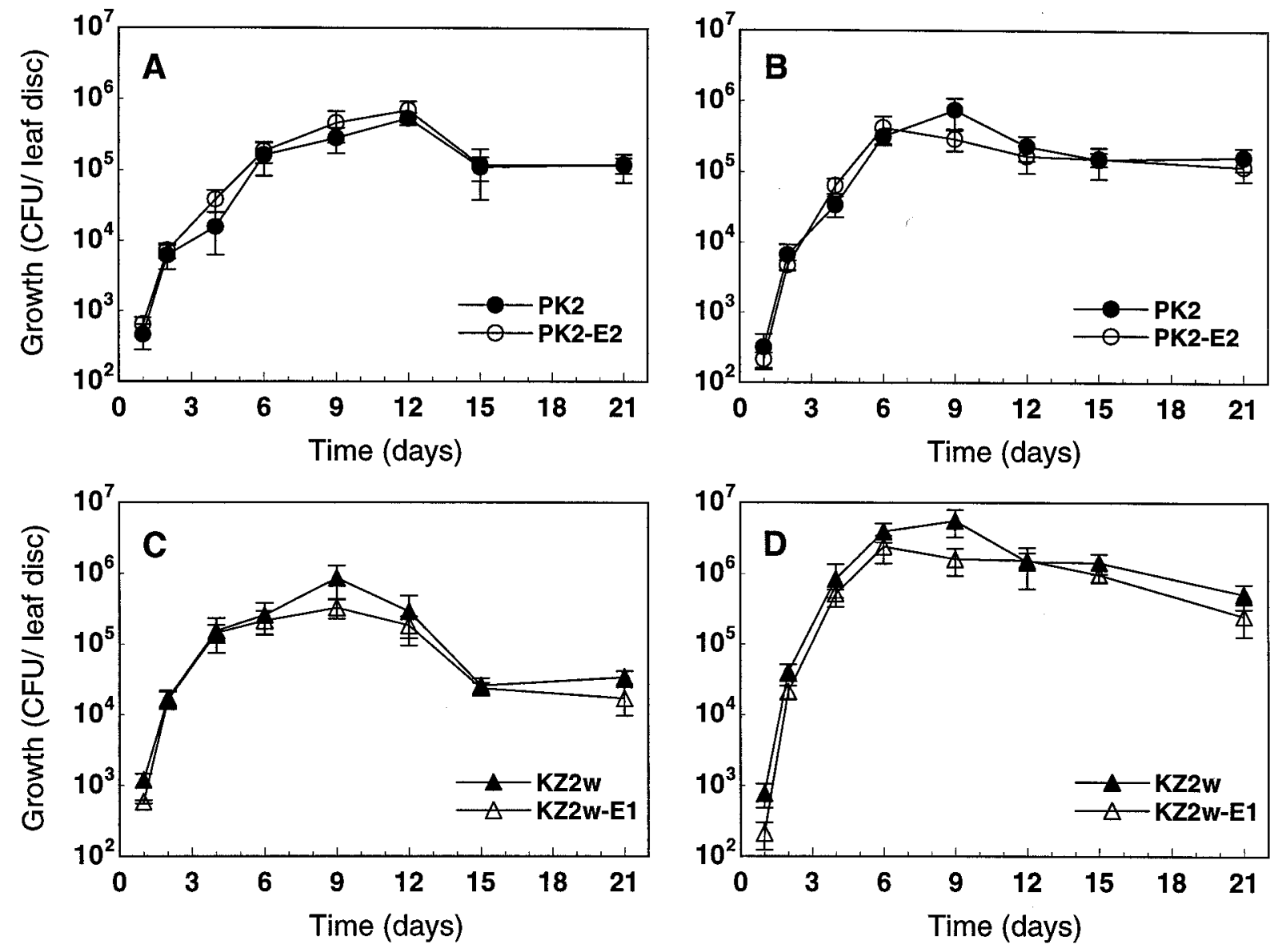

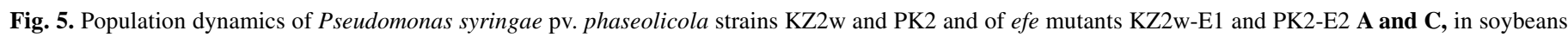
cv. Maple Arrow and $\mathbf{B}$ and D, beans cv. Red Kidney. The standard deviation was calculated from three series of samples with 20 leaf discs. 
Reymond and Farmer (31) concluded that a pathogen might take advantage of this situation by synthesizing a plant defense signal, thereby altering the defense response of the plant. Interestingly, we observed no increase in ethylene production in soybean leaves inoculated with the ethylene-negative mutant Pseudomonas syringae pv. glycinea 7a/90-E1, although typical disease symptoms appeared (Fig. 6). Obviously, ethylene has no direct role as a signal in the defense of soybean plants against Pseudomonas syringae pv. glycinea. Experiments are in progress to compare the spectrum of plant defense genes induced by wild-type strains with those induced by efe mutants.

\section{ACKNOWLEDGMENTS}

We thank A. F. Bent for providing seeds of the ethylene-insensitive soybean line, K. Nishiyama for providing bacterial strains, and $\mathrm{M}$. Ullrich for critical reading of the manuscript.

\section{LITERATURE CITED}

1. Abeles, F. B., Morgan, P. W., and Saltveit, M. E. 1992. Ethylene in Plant Biology. 2nd ed. Academic Press, San Diego.

2. Ben-David, A., Bashan, Y., and Okon, Y. 1986. Ethylene production in pepper (Capsicum annuum) leaves infected with Xanthomonas campestris pv. vesicatoria. Physiol. Mol. Plant Pathol. 29:305-316.

3. Bender, C. L. 1999. Chlorosis-inducing phytotoxins produced by Pseudomonas syringae. Eur. J. Plant Pathol. 105:1-12.

4. Bender, C. L., Stone, H. E., Sims, J. J., and Cooksey, D. A. 1987. Reduced pathogen fitness of Pseudomonas syringae pv. tomato Tn5 mutants defective in coronatine production. Physiol. Mol. Plant Pathol. 30:273-283.

5. Bent, A. F., Innes, R. W., Ecker, J. R., and Staskawicz, B. J. 1992. Disease development in ethylene-insensitive Arabidopsis thaliana infected with virulent and avirulent Pseudomonas and Xanthomonas pathogens. Mol. Plant-Microbe Interact. 5:372-378.

6. Bereswill, S., Bugert, P., Völksch, B., Ullrich, M., Bender, C. L., and Geider, K. 1994. Identification and relatedness of coronatine-producing Pseudomonas syringae pathovars by PCR analysis and sequence determination of the amplification products. Appl. Environ. Microbiol. 60:2924-2930.

7. Boller, T. 1991. Ethylene in pathogenesis and disease resistance. Pages 293-324 in: The Plant Hormone Ethylene. A. K. Mattoo and J. C. Suttle, eds. CRC Press, Boca Raton, FL.

8. Dong, X. 1998. SA, JA, ethylene, and disease resistance in plants. Curr. Opin. Plant Biol. 1:316-323.

9. Durbin, R. D. 1991. Bacterial phytotoxins: Mechanisms of action. Experientia 47:776-783.

10. Dutta, S., and Biggs, R. H. 1991. Regulation of ethylene biosynthesis in citrus leaves infected with Xanthomonas campestris pv. citri. Physiol. Plant 82:225-230.

11. Feys, B. J. F., Benedetti, C. E., Penfold, C. N., and Turner, J. G. 1994. Arabidopsis mutants selected for resistance to the phytotoxin coronatine are male sterile, insensitive to methyl jasmonate, and resistant to a bacterial pathogen. Plant Cell 6:751-759.

12. Fukuda, H., Ogawa, T., Ishihara, K., Fujii, T., Nagahama, K., Omata, T., Inoue, Y., Tanase, S., and Morino, Y. 1992. Molecular cloning in Escherichia coli, expression and nucleotide sequence of the gene for the ethylene forming enzyme of Pseudomonas syringae pv. phaseolicola PK2. Biochem. Biophys. Res. Commun. 188:826-832.

13. Fukuda, H., Ogawa, T., and Tanase, S. 1993. Ethylene production by micro-organisms. Pages 275-306 in: Advances in Microbial Physiology. Vol. 35. A. H. Rose, ed. Academic Press, New York.

14. Fukuda, H., Ogawa, T., Tazaki, M., Nagahama, K., Fujii, T., Tanase, S., and Morino, Y. 1992. Two reactions are simultaneously catalyzed by a single enzyme: The arginine-dependent simultanous formation of two products, ethylene and succinate, from 2-oxoglutarate by an enzyme from Pseudomonas syringae. Biochem. Biophys. Res. Commun. 188:483-489.

15. Geider, K., Hohmeyer, C., Haas, R., and Meyer, T. F. 1985. A plasmid cloning system utilizing replication functions of the filamentous bacteriophage fd. Gene 33:341-349.

16. Goto, M., Ishida, Y., Takikawa, Y., and Hyodo, H. 1985. Ethylene production by the kudzu strains of Pseudomonas syringae pv. phaseolicola causing halo blight in Pueraria lobata (Willd) Ohwi. Plant Cell Physiol. 26:141-150

17. Goto, M., Yaguchi, Y., and Hyodo, H. 1980. Ethylene production in citrus leaves infected with Xanthomonas citri and its relation to defoliation. Physiol. Plant Pathol. 16:343-350.
18. Greulich, F., Yoshihara, T., and Ichihara, A. 1995. Coronatine, a bacterial phytotoxin, acts as a stereospecific analog of jasmonate type signals in tomato cells and potato tissues. J. Plant Physiol. 147:359-366.

19. Hoffman, T., Schmidt, J. S., Zheng, X., and Bent, A. F. 1999. Isolation of ethylene-insensitive soybean mutants that are altered in pathogen susceptibility and gene-for-gene disease resistance. Plant Physiol. 119:935-949.

20. Keen, N. T., Tamaki, S., Kobayashi, D., and Trollinger, D. 1988. Improved broad-host-range plasmids for DNA cloning in gram-negative bacteria. Gene 70:191-197.

21. King, E. O., Ward, M. K., and Raney, D. E. 1954. Two simple media for the demonstration of pyocyanin and fluorescin. J. Lab. Clin. Med. 44:301-307.

22. Kitajima, S., and Sato, F. 1999. Plant pathogenesis-related proteins: Molecular mechanisms of gene expression and protein function. J. Biochem. 125:1-8.

23. Lu, S.-F., Tzeng, D. D., and Hsu, S.-T. 1989. In vitro and in vivo ethylene production in relation to pathogenesis of Pseudomonas solanacearum (Smith) Smith on Lycopersicon esculentum M. Plant Prot. Bull. (Taichung) 31:60-76.

24. Lund, S. T., Stall, R. E., and Klee, H. J. 1998. Ethylene regulates the susceptible response to pathogen infection in tomato. Plant Cell 10:371-382.

25. Mattoo, A. K. and Suttle, J. C. 1991. The Plant Hormone Ethylene. CRC Press, Boca Raton, FL.

26. May, R., Völksch, B., and Kampmann, G. 1997. Antagonistic activities of epiphytic bacteria from soybean leaves against Pseudomonas syringae pv. glycinea in vitro and in planta. Microbiol. Ecol. 34:118-124.

27. Mittal, S. and Davis, K. R. 1995. Role of the phytotoxin coronatine in the infection of Arabidopsis thaliana by Pseudomonas syringae pv. tomato. Mol. Plant-Microbe Interact. 8:165-171.

28. Nagahama, K., Ogawa, T., Fujii, T., and Fukuda, H. 1992. Classification of ethylene-producing bacteria in terms of biosynthetic pathways to ethylene. J. Ferment. Bioeng. 73:1-5.

29. Ogawa, T., Takahashi, M., Fujii, T., Tazaki, M., and Fukuda, H. 1990. The role of NADH:Fe(III)EDTA oxidoreductase in ethylene formation from 2-keto-4-methylthiobutyrate. J. Ferment. Bioeng. 69:287-291.

30. Pegg, G. F. and Cronshaw, D. K. 1976. The relationship of in vitro to in vivo ethylene production in Pseudomonas solanacearum infection of tomato. Physiol. Plant Pathol. 9:145-154.

31. Reymond, P., and Farmer, E. E. 1998. Jasmonate and salicylate as global signals for defense gene expression. Curr. Opin. Plant Biol. 1:404-411.

32. Sambrook, J., Fritsch, E. F., and Maniatis, T. 1989. Molecular Cloning: A Laboratory Manual. 2nd ed. Cold Spring Harbor Laboratory, Cold Spring Harbor, NY.

33. Sato, M., Watanabe, K., Yazawa, M., Takikawa, Y., and Nishiyama, K. 1997. Detection of new ethylene-producing bacteria, Pseudomonas syringae pvs. cannabina and sesami, by PCR amplification of genes for the ethylene-forming enzyme. Phytopathology 87:1192-1196.

34. Simon, R., Priefer, U., and Pühler, A. 1983. A broad host range mobilization system for in vivo genetic engineering: Transposon mutagenesis in Gram-negative bacteria. Bio/Technology 1:784-791.

35. Stall, R. E., and Hall, C. B. 1984. Chlorosis and ethylene production in pepper leaves infected by Xanthomonas campestris pv. vesicatoria. Phytopathology 74:373-375.

36. Takikawa, Y., Ando, Y., Hamaya, E., Tsuyumu, S., and Goto, M. 1988. Identification of the pathogens responsible for bacteriosis of tea plant occurred in 1983. Ann. Phytopath. Soc. Japan 54:224-228.

37. Völksch, B., Laplace, F., and Fritsche, W. 1984. Untersuchungen zur Variabilität der Phaseolotoxinbildung bei Pseudomonas syringae pv. phaseolicola. Zentbl. Mikrobiol. 139:109-118.

38. Völksch, B., and Weingart, H. 1997. Comparison of ethylene-producing Pseudomonas syringae strains isolated from kudzu (Pueraria lobata) with Pseudomonas syringae pv. phaseolicola and Pseudomonas syringae pv. glycinea. Eur. J. Plant. Pathol. 103:795-802.

39. Völksch, B., and Weingart, H. 1998. Toxin production by pathovars of Pseudomonas syringae and their antagonistic activities against epiphytic microorganisms. J. Basic Microbiol. 38:135-145.

40. Weiler, E. W., Kutchan, T. M., Gorba, T., Brodschelm, W., Neisel, U., and Bublitz, F. 1994. The Pseudomonas phytotoxin coronatine mimics octadecanoid signaling molecules of higher plants. FEBS Lett. 345:9-13.

41. Weingart, H., and Völksch, B. 1997. Ethylene production by Pseudomonas syringae pathovars in vitro and in planta. Appl. Environ. Microbiol. 63:156-161.

42. Weingart, H., Völksch, B., and Ullrich, M. S. 1999. Comparison of ethylene production by Pseudomonas syringae and Ralstonia solanacearum. Phytopathology 89:360-365.

43. Zhang, J.-H., Quigley, N. B., and Gross, D. C. 1997. Analysis of the $s y r P$ gene, which regulates syringomycin synthesis by Pseudomonas syringae pv. syringae. Appl. Environ. Microbiol. 63:2771-2778. 